\title{
KEPEMIMPINAN DALAM BISNIS ISLAM
}

\author{
Umi Arifah $^{1}$, Afifatul Azizah ${ }^{2}$, Dina Kurnia Salwa ${ }^{3}$, Ida Rohyanti ${ }^{4}$ \\ Institut Agama Islam Nahdlatul Ulama (IAINU) Kebumen \\ umiarifah87@gmail.com ${ }^{1}$
}

\begin{abstract}
This study describes the theories of leadership and leadership in Islamic business. The methodology used in this study uses a library research approach, and data collection is carried out by studying and exploring journals, books, and supporting documents others that are relevant to the studies conducted. The results of the study show that Islamic business leadership must apply Islamic principles, both in terms of morals, ethics, responsibility and others. The four leadership models of the Messenger of Allah, namely Shiddiq, amanah, tabligh, fathanah, are the best traits and characters to be used as tauladan in developing individual leadership potential nor groups. The four traits are a synergistic and complementary whole. The variables of these qualities have been tested for success as have the success of the Prophets and Apostles of Allah. Business is carried out to continue to innovate new, so that when the business suffers a loss, leaders and employees conduct deliberations to get the latest innovations to overcome the problem.
\end{abstract}

Keywords: Leadership, Leadership Theory, Islamic Business

\begin{abstract}
ABSTRAK
Kajian ini mendeskripsikan teori-teroi kepemimpinan dan kepemimpinan dalam bisnis Islam. Metodologi yang digunakan dalam kajian ini menggunakan pendekatan kepustakaan (library research), dan pengumpulan data dilakukan dengan menelaah dan mengeksplor jurnal, buku, dan dokumen pendukung lainnya yang relevan dengan kajian yang dilakukan. Hasil kajian menunjukkan bahwa kepemimpinan bisnis Islam harus menerapkan prinsip-prinsip Islam, baik dalam hal moral, etika, tanggung jawab dan lainnya. Keempat model kepemimpinan Rasulullah yakni Shiddiq, amanah, tabligh, fathanah, adalah sebuah sifat dan karakter yang terbaik untuk dijadikan tauladan dalam mengembangkan potensi kepemimpinan individu maupun kelompok. Keempat sifat tersebut adalah satu kesatuan yang sinergis dan saling melengkapi. Variabel dari sifat-sifat tersebut sudah teruji kesuksesannya sebagaimana suksesnya para Nabi dan Rasul Allah. Bisnis dilakukan untuk terus melakukan inovasi yang baru, sehingga ketika usaha tersebut mengalami kerugian, pemimpin serta karyawan melakukan musyawarah untuk mendapatkan inovasi-inovasi terbaru untuk mengatasi masalah tersebut.
\end{abstract}

Kata Kunci: Kepemimpinan, Teori Kepemimpinan, Bisnis Islam 


\section{PENDAHULUAN}

Peran kepemimpinan seringkali menjadi ukuran dalam mencari sebabsebabatuh bangunnya suatu organisasi. Dimensi kepemimpinan memiliki aspekaspek yang sangat luas, serta merupakan proses yang melibatkan berbagai komponen di dalamnya yang saling mempengaruhi. Menurut Kartono (2004), kepemimpinan muncul bersama-sama adanya peradaban manusia yaitu sejak zaman nabi dan nenek moyang manusia yang berkumpul bersama, kemudian bekerja bersama-sama untuk mempertahankan eksistensi hidupnya yang menantang kebuasan binatang dan alam di sekitarnya. Sejak itulah terjadi kerja antarmanusia dan ada unsur kepemimpinan. Pada saat itu pribadi yang ditunjuk sebagai pemimpin ialah orang-orang yang paling kuat, paling cerdas dan paling berani. Seorang pemimpin adalah orang yang mengarahkan, mempengaruhi, dan memimpin orang lain (bawahan dan pengikut) untuk mencapai tujuan. Pemimpin dapat dikatakan baik apabila memiliki sikap kepercayaan diri, menciptakan visi dan memotivasi orang lain untuk mencapai visi mereka. Menurut James M. Black dalam Rivai (2009) menyatakan bahwa kepimpinan adalah kemampuan meyakinkan orang lain supaya bekerja sama dibawah pimpinannya sebagai suatu tim untuk mencapai atau melakukan suatu tujuan tertentu.

Menurut Farrag Galanou (2015), Rasulullah SAW dalam bisnis Islam mengajarkan untuk menjadi pedagang yang jujur dan dari segi etika harus baik. Banyak pelajaran yang seharusnya dapat kita lihat seperti adanya kegagalan, krisis utang dan perilaku seorang pemimpin tidak menunjukkan seorang pebisnis yang baik seperti tidak jujur, egois dengan mengorbankan kesejahteraan orang lain, dan memaksa karyawan untuk menyesuaikan diri dalam lingkungan organisasi yang munafik.

\section{METODE PENELITIAN}

Kajian ini dilakukan dengan menggunakan metode atau pendekatan kepustakaan (library research). Studi Kepustakaan merupakan serangkaian kegiatan yang berkaitan dengan metode pengumpulan data pustaka, membaca dan mencatat serta mengolah bahan penelitian (Zed, 2003:3). Penelitian studi kepustakaan memuat empat ciri utama yang perlu diperhatikan yaitu : a) Penulis 
berhadapan langsung dengan teks atau data angka, bukan dari pengetahuan langsung di lapangan; b) Data pustaka bersifat siap pakai, yaitu peneliti tidak secara langsung terjun kelapangan, namun peneliti berhadapan langsung dengan sumber data yang di perpustakaan; c) Data pustaka merupakan sumber sekunder, yang berarti bahwa peneliti memperoleh bahan atau data bukan dari data di lapangan; d) Kondisi data pustaka tidak dibatasi oleh ruang dan waktu (Zed, 2003:4-5). Teknik pengumpulan data dalam kajian ini dilakukan dengan melakukan telaah dan mengeksporasi jurnal, buku dan dokumen pendukung lainnya yang relevan dengan kajian yang dilakukan.

\section{PEMBAHASAN}

\section{Konsep Kepemimpinan}

Kajian kepemimpinan berada dalam kerangka konsep hubungan manusia. Banyak pakar manajemen dan kepemimpinan mengajukan defenisi yang dapat dijadikan kerangka konseptual membahas teori kepemimpinan (Syafaruddin dan Asrul : 2015). Hersey dan Blanchard (1982) berpendapat bahwa kepemimpinan adalah proses mempengaruhi aktifitas seseorang atau kelompok untuk mencapai tujuan dalam situasi tertentu.

Kepemimpinan merupakan terjemahan dari kata Leadership yang berasal dari kata Leader. Pemimpin ialah orang yang memimpin, sedangkan pimpinan ialah jabatannya. Dalam pengertian lain, secara etimologi istilah kepemimpinan berasal dar kata dasar pimpin yang atinya bimbing atau tuntun. Dari kata tuntun maka lahirlah kata kerja memimpin yang artinya membimbing atau menuntun (Didin Kurniawan \& Imam Machali : 206).

Kepemimpinan merupakan upaya mempengaruhi kegiatan pengikut melalui proses komunikasi untuk mencapai tujuan tertentu. Ahli lain berpendapat bahwa kepemimpinan adalah sebagai seni untuk mengatur individu dan masyarakat, serta memotivasi semangat mereka untuk meraih tujuan yang telah ditetapkan. Pendapat lain juga menyatakan bahwa kepemimpinan sebagai seni untuk mempengaruhi dan mengarahkan orang lain dengan metode tertentu agar mereka berusaha untuk taat, loyal, dan membantu dalam satu cara untuk meraih tujuan yang telah ditetapkan (John F. dan Robert B : 1960). 
Seorang pemimpin memiliki karekter dan sifat tertentu, pemimpin menduduki jabatan yang tinggi sebuah struktur organisasi atau perusahaan. Seorang pemimpin dengan kekuasan yang di milikinya akan mempengaruhi perilaku orang lain dengan metode yang memungkinkan, sehingga mereka loyal dan para bawahan juga berkenaan untuk mematuhi segala perintahnya dengan ridha dan segenap perasaan jiwa. Sebagai seorang pemimpin ia menggunakan sepenuh hati dan bisa di terima oleh bawahannya.

Beberapa unsur yang mendasari dari sifat-sifat dasar yang ada dalam merumuskan definisi kepemimpinan (Tatang M. Amirin : 1984), yaitu:

a. Unsur-unsur yang mendasari, terdiri dari : 1) Kemampuan mempengaruhi orang lain (kelompok/bawahan); 2) Kemampuan mengarahkan atau memotivasi tingkah laku orang lain atau kelompok; dan 3) Kemampuan bekerjasama untuk mencapai tujuan yang diinginkan.

b. Sifat dasar kepemimpinan, terdiri dari : 1) Kecakapan memahami individual, artinya mengetahui bahwa setiap manusia mempunyai daya motivasi yang berbeda pada berbagai saat dan keadaan yang berlainan; 2) Kemampuan untuk menggugah semangat dan memberi inspirasi; dan 3)Kemampuan untuk melakukan tindakan dalam suatu cara yang dapat mengembangkan suasana (iklim) yang mampu memenuhi dan sekaligus menimbulkan dan mengendalikan motivasi-motivasi.

\section{Teori-teori Kepemimpinan}

\section{a. Teori Pengaruh Kekuasaan}

Teori yang dikemukakan oleh French dan Raven (1959) menyatakan bahwa kepemimpinan bersumber pada kekuasaan dalam satu kelompok atau organisasi. Dengan kata lain, orang-orang yang memiliki akses terhadap sumber kekuasaan dalam suatu kelompok atau organisasi tertentu akan mengendalikan atau memimpin kelompok atau organisasi itu.

Sumber kekuasaan terdiri dari tiga macam (French dan Raven : 1959) sebagai berikut:

1) Kekuasaan yang bersumber pada kedudukanKekuasaan yang bersumber pada kedudukan terbagi lagi ke dalam beberapa jenis sebagai berikut: 
a) Kekuasaan Formal atau legal

Jenis ini adalah komandan tentara, kepala dinas, presiden atau perdana mentri dan sebagainya yang mendapat kekuasaan karena ditunjuk dan/atau diperkuat dengan peraturan atau perundangan yang resmi.

b) Kendali atas Sumber dan Ganjaran

Majikan yang menggaji karyawan, majikan yang mengupah buruh, kepala suku atau kepala kantor yang dapat member ganjaran kepada bawahannya, dan sebagainya, memimpin berdasarkan sumber kekuasaan seperti ini.

c) Kendali atas Hukum

Ganjaran biasanya terkait dengan hukuman sehingga kendali atas ganjaran biasa juga kendali atas hukuman. Walaupun demikian, ada kepemimpinan yang yang sumbernya hanya kendali atas hukuman saja, ini merupakan kepemimpinan yang didasarkan pada rasa takut. Contoh para preman yang memungut pajak kepada pedagang, pedagang akan tunduk kepada preman karena takut akan mendapat perlakuan kasar.

d) Kendali atas Informasi

Informasi adalah ganjaran positif bagi orang yang memerlukannya, sehingga siapa pun yang menguasai informasi dapat menjadi pemimpin. Misal adalah orang yang paling tahu arah jalan maka otomatis dia akan menjadi pimpinan rombongan.

e) Kendali Ekologi/lingkungan

Sumber kekuasaan ini dinamakan juga perekayasa situasi. Contoh adalah kendali atas penempatan jabatan. Seorang atasan, manager, atau kepala bagian personality mempunyai kekuasaan atas bawahannya, karena ia boleh menentukan posisi anggotanya.

2) Kekuasaan yang Bersumber pada Kepribadian

Kekuasaan yang bersumber pada kepribadian berawal dari sifat-sifat pribadi, yaitu sebagai berikut:

a) Keahlian atau Ketrampilan

Dalam agama Islam, orang yang menjadi imam adalah orang yang paling fasih membaca ayat Al-Qur'an. Demikian pula dalam pesawat atau kapal, 
orang yang paling ahli dalam mengemudilah yang akan menjadi pemimpin.

b) Persahabatan atau Kesetiaan

Sifat dapat bergaul, setia kawan atau setia kepada kelompok dapat merupakan sumber kekuasaan, sehingga seseorang dianggap sebagai pemimpin.

c) Karisma

Ciri kepribadian yang menyebabkan timulnya kewibawaan pribadi dari pemimpin juga merupakan salah satu sumber kekuasaan dalam proses kepemimpinan. Mengenai hal ini dibicarakan tersendiri dalam teori bakat.

3) Kekuasaan yang Bersumber pada Politik

Kekuasaan yang bersumber pada politik terdiri atas beberapa jenis (Pfeffer:1981) sebagai berikut:

1) Kendali atas proses pembuatan keputusan: dalam organisasi ketua menetukan apakah suatu keputusan akan dibuat dan dilaksanakan atau tidak.

2) Koalisi: kepemimpinan atas dasar sumber kekuasaan politik ditentukan juga atas hak atau kewenangan untuk membuat kerja sama dengan kelompok lain.

3) Partisipasi: pemimpin mengatur partisipasi anggotanya, siapa yang boleh berpartisipasi, dalam bentuk apa tiap anggota berpartisipasi, dan sebagainya.

4) Institusionalisasi: pemimpin agama menikahkan pasangan suami istri, menentukan terbentuknya keluarga baru. Notaris atau hakim menetukan berdirinya suatu yayasan atau perusahaan baru.

\section{b. Teori Bakat}

Teori bakat dinamakan juga teori sifat, teori karismatik atau teori transformasi. Inti dari teori ini adalah bahwa kepemimpinan terjadi karena sifatsifat atau bakat yang khas yang terdapat dalam diri pemimpin yang dapat diwujudkan dalam perilaku kepemimpinan. Sifat atau bakat itu dinamakan karisma atau wibawa.

Teori sifat disebut juga teori genetik, karena menganggap bahwa pemimpin itu dilahirkan bukan dibentuk. Teori ini menjelaskan bahwa eksistensi seorang 
pemimpin dapat dilihat dan dinilai berdasarkan sifat-sifat sejak lahir sebagai sesuatu yang diwariskan (Siagian dalam Umam: 1977). Teori ini mengatakan bahwa kepemimpinan diidentifikasikan berdasarkan atas sifat atau ciri yang dimiliki oleh para pemimpin. Pendekatan ini mengemukakan bahwa ada karakteristik tertentu seperti fisik, sosialisasi, dan intelegensi (kecenderungan) yang esensial bagi kepemimpinan yang efektif, yang merupakan kualitas bawaan

seseorang.(Connie Chairunnisa: 2017) Berdasarkan teori kepemimpinan ini, asumsi dasar yang dimunculkan adalah kepemimpinan memerlukan serangkaian sifat, ciri, atau perangai tertentu yang menjamin keberhasilan setiap situasi. Keberhasilan seorang pemimpin diletakkan pada kepribadian pemimpin itu sendiri Teori bakat menurut Hourse (1977) bahwa karisma yang berupa bakat atau sifat adalah hal yang dapat dijelaskan secara objektif ilmiah, sehingga dapat diteliti, diukur, dan dibuktikan keberadaanya. Menurut Baas teori bakat (1985) bahwa ada factor-faktor tambahan lain yang menyebabkan lahirnya kepemimpinan karismatik selain faktor bawaan sejak lahir yang dikemukakan oleh Hourse, yaitu factor anteseden (hal yang mendahului terjadinya seorang pemimpin), faktor atribusi (keyakinan sendiri) dan faktor konsekuensi dari kepemimpinan.

Teori bakat menurut Conger dan Kanungo (1987) bahwa kepemimpinan karismatik terutama bersifat atributif, yaitu karena adanya ciri-ciri tertentu dari pemimpin yang dipersepsikan oleh para pengikut berdasarkan pengamatan pengikut terhadap prilaku pemimpin. Menurut Robert (1984) teori tranformasional bahwa pemimpin karismatik dapat juga terjadi dalam kelompokkelompok yang sangat terorganisasi. Berbeda dari pendapat sebelumnya yang seakan-akan menyatakan bahwa kepemimpinan karismatik tidak dapat berjalan pada kelompok-kelompok yang sangat terorgaisasi.

Ykul (1989) mengemukakan bahwa sejarah telah mencatat pemimpinpemimpin karismatik yang telah memberi dampak positif yang sangat luar biasa kepada kelompoknya, bahkan terhadap umat manusia secara keseluruhan, seperti Mahatma Gandhi dan Martin Luther King. Di pihak lain sejarah juga mencatat pemimpin-pemimpin karismatik yang memberikan dampak negative dan kehancuran, seperti Adolf Hitler. Musser (1987) mengusulkan kriteria yang 
berbeda antara pemimpin karismatik yang positif dan negatif. Ciri pemimpin karismatik yang negatif adalah yang lebih mementingkan tujuan dirinya sendiri daripada idiologi-idiologinya.

\section{c. Teori Perilaku}

Teori perilaku memusatkan perhatiannya pada perilaku pemimpin dalam kaitannya dengan struktur dan organisasi kelompok. Oleh karena itu, teori prilaku ini lebih sesuai untuk kepemimpinan dalam lingkungan organisasi atau perusahaan, karena peran pemimpin digariskan dengan jelas. Mintzberg (1973) mengemukakan sepuluh peran pemimpin (manager) sebagai berikut; Peran dalam hubungan antarpribadi adalah sebagai pemimpin, penghubung dan panutan (figurehead). Peran yang berkaitan dengan pemrosesan informasi adalah sebagai pemantau, penyebaran informasi dan juru bicara. Peran yang berkaitan dengan pembuatan keputusan adalah sebagai wiraswasta, penyelesaian gangguan, pengalokasian sumber, dan negosiator. Bagaimana seorang pemimpin memenuhi kesepuluh peran itu, hal itu akan ditentukan bagaimana kepemimpinannya. Mereka akan memiliki kecocokan dengan salah satu peran, dan biasanya mereka akan unggul dalam hal itu.

Page (Page, 1985 \& Tornow, 1987) juga memusatkan teori kepemimpinannya pada peran yang dibawakan pemimipin dalam posisi managerial. Menurutnya ada Sembilan kewajiban dan tanggung jawab manager dalam organisasi. Yaitu penyelia (supervising), perencan dan pengorganisasi, pembuat keputusan, pemantau indicator, pengendalian, perwakilan, pengkooordinasi, konsultasi, dan administrasi. Sebagai manager sudah barang tentu seseorang yang dapat menduduki sembilan peran tersebut. Namun, setiap orang memiliki kemampuan tersendiri, sehingga ada yang kuat di peran tertentu dan lemah di peran yang lain.

\section{d. Teori Great Man}

Menurut teori ini seorang pemimpin besar terlahir sebagai pemimpin yang memiliki berbagai ciri-ciri individu yang sangat berbeda dengan kebanyakan manusia lainnya. Ciri-ciri individu tersebut mencakup karisma, intelegensi, kebijaksanaan, dan dapat menggunakan kekuasaan yang dimilikinya untuk membuat berbagai keputusan yang memberi dampak besar bagi sejarah manusia. Karisma sendiri menunjukkan kepribadian seseorang yang dicirikan oleh pesona 
pribadi, daya tarik, yang disertai dengan kemampuan komunikasi interpersonal dan persuasi yang luar biasa. Menurut Carlyle, pemimpin besar akan lahir saat dibutuhkan oleh situasi sehingga para pemimpin ini tidak bisa dibuat (Ismail Solihin: 2009)

\subsection{Tipe-tipe Kepemimpinan}

Tipe kepemimpinan dapat disebut dengan model (gaya) kepemimpinan seseorang. Tipe kepemimpinan yang secara luas dikenal adalah sebagai berikut.

\section{a. Tipe Otoriter}

Disebut juga tipe kepemimpinan authoritarian. Dalam kepemimpinan ini, pemimpin bertindak sebagai diktator terhadap anggota kelompoknya. Baginya memimpin adalah menggerakkan dan memaksa kelompok. Batasan kekuasaan dari pemimpin otoriter hanya dibatasi oleh undang-undang. Bawahan hanya bersifat sebagai pembantu, kewajiban bawahan hanyalah mengikuti dan menjalankan perintah dan tidak boleh membantah atau mengajukan saran. Mereka harus patuh dan setia kepada pemimpin secara mutlak.

Kelebihan dari tipe kepemimpinan otoriter yaitu : 1) Keputusan dapat diambil secara cepat; 2) Mudah dilakukan pengawasan. Sedangkan kelemahannya yaitu : 1) Pemimpin yang otoriter tidak menghendaki rapat atau musyawarah; 2) Setiap perbedaan diantara anggota kelompoknya diartikan sebagai kelicikan, pembangkangan, atau pelanggaran disiplin terhadap perintah atau instruksi yang telah diberikan; 3) Inisiatif dan daya pikir anggota sangat dibatasi, sehingga tidak diberikan kesempatan untuk mengeluarkan pendapatnya; 4) Pengawasan bagi pemimpin yang otoriter hanyalah berarti mengontrol, apakah segala perintah yang telah diberikan ditaati atau dijalankan dengan baik oleh anggotanya; 5) Mereka melaksanakan inspeksi, mencari kesalahan dan meneliti orang-orang yang dianggap tidak taat kepada pemimpin, kemudian orang-orang tersebut diancam dengan hukuman, dipecat, dsb. Sebaliknya, orang-orang yang berlaku taat dan menyenangkan pribadinya, dijadikan anak emas dan bahkan diberi penghargaan; 6) Kekuasaan berlebih ini dapat menimbulkan sikap menyerah tanpa kritik dan kecenderungan untuk mengabaikan perintah dan 
tugas jika tidak ada pengawasan langsung; dan 7) Dominasi yang berlebihan mudah menghidupkan oposisi atau menimbulkan sifat apatis.

\section{b. Tipe Laissez Faire}

Dalam tipe kepemimpinan ini sebenarnya pemimpin tidak memberikan kepemimpinannya, dia membiarkan bawahannya berbuat sekehendaknya. Pemimpin akan menggunakan sedikit kekuasaannya untuk melakukan tugas mereka. Dengan demikian sebagian besar keputusan diambil oleh anak buahnya. Pemimpin semacam ini sangat tergantung pada bawahannya dalam membuat tujuan itu. Mereka menganggap peran mereka sebagai 'pembantu' usaha anak buahnya dengan cara memberikan informasi dan menciptakan lingkungan yang baik.

Kelebihan dari tipe Laissez Faire yaitu : 1) Keputusan berdasarkan keputusan anggota; 2) Tidak ada dominasi dari pemimpin. Sedangkan kekurangan dari teori ini yaitu : 1) Pemimpin sama sekali tidak memberikan control dan koreksi terhadap pekerjaan bawahannya; 2) Pembagian tugas dan kerja sama diserahkan sepenuhnya kepada bawahannya tanpa petunjuk atau saran-saran dari pemimpin. Dengan demikian mudah terjadi kekacauan dan bentrokan; 3) Tingkat keberhasilan anggota dan kelompok semata-mata disebabkan karena kesadaran dan dedikasi beberapa anggota kelompok, dan bukan karena pengaruh dari pemimpin. Struktur organisasinya tidak jelas atau kabur, segala kegiatan dilakukan tanpa rencana dan tanpa pengawasan dari pimpinan.

\section{c. Tipe Demokratis}

Hubungan pemimpin dengan anggota bukan sebagai majikan dengan bawahan, tetapi lebih seperti kakak dengan saudara-saudaranya. Dalam tindakan dan usaha-usahanya ia selalu berpangkal kepada kepentingan dan kebutuhan kelompoknya, dan mempertimbangkan kesanggupan dan kemampuan kelompoknya.

Kelebihan dari teori demokratis yaitu : 1) Dalam melaksanalan tugasnya, ia mau menerima dan bahkan mengharapkan pendapat dan saran dari kelompoknya; 2) Ia mempunyai kepercayaan pula pada anggotanya bahwa mereka mempunyai kesanggupan bekerja dengan baik dan bertanggung jawab; 
dan 3) Ia selalu berusaha membangun semangat anggota kelompok dalam menjalankan dan mengembangkan daya kerjanya dengan cara memupuk rasa kekeluargaan dan persatuan. Di samping itu, ia juga memberi kesempatan kepada anggota kelompoknya agar mempunyai kecakapan memimpin dengan jalan mendelegasikan sebagian kekuasaan dan tanggung jawabnya. Sedangkan kekurangan dari teori ini yaitu : 1) Proses pengambilan keputusan akan memakan waktu yang lebih banyak; dan 2) Sulitnya pencapaian kesepakatan.

\section{d. Tipe Pseudo-demokratis}

Tipe ini disebut juga semi demokratis atau manipulasi diplomatik. Pemimpin yang bertipe pseudo-demokratis hanya tampaknya saja bersikap demokratis padahal sebenarnya dia bersikap otokratis. Misalnya jika ia mempunyai ide-ide, pikiran, atau konsep yang ingin diterapkan di lembaga Pendidikannya, maka hal tersebut akan dibicarakan dan dimusyawarahkan dengan bawahannya, tetapi situasi diatur dan diciptakan sedemikian rupa sehingga pada akhirnya bawahan didesak agar menerima ide atau pikiran tersebut sebagai keputusan bersama. Pemimpin ini menganut demokrasi semu dan lebih mengarah kepada kegiatan pemimpin yang otoriter dalam bentuk yang halus, samar-samar, dan yang mungkin dilaksanakan tanpa disadari bahwa tindakan itu bukan tindakan pimpinan yang demokratis.

\section{e. Tipe Kharismatik}

Seorang pemimpin yang kharismatik memiliki karakteristik yang khas yaitu daya tariknya yang sangat memikat sehingga mampu memperoleh pengikut yang sangat besar dan para pengikutnya tidak selalu dapat menjelaskan secara konkret mengapa orang tertentu itu dikagumi. Pengikutnya tidak mempersoalkan nilai yang dianut, sikap, dan perilaku serta gaya dari si pemimpin.

\section{Sifat Kepemimpinan Dalam Bisnis Islam}

Pemimpin Islam memegang teguh prinsip-prinsip kepemimpinan dengan selalu memberikan ruang secara lebar untuk menampung ide-ide kreatif para pekerjanya secara adil tanpa melihat siapapun yang menyampaikamnya. 
Kemudian membahas semua semua ide yang masuk dalam sebuah wadah khusus yakni musyawarah untuk menentukan ide-ide mana saja yang layak untuk digunakan dan akhirnya diteruskan menjadi sebuah penciptaan inovasi produk baru yang memiliki daya guna dan nilai jual baru suatu produk tersebut. Jika inovasi produk bisa terus berjalan dengan baik maka keberlangsungan usahanya tentu akan terus berjalan lancar dan usahanya akan tetap dapat bersaing dengan perusahaan lain yang sejenis ditengah persaingan usaha yang semakin ketat.

Dengan demikian, kepemimpinan Islam bukanlah kepemimpinan tirani dan tanpa koordinasi. Pemimpin Islam, selalu didasari dengan prinsip-prinsip Islam bermusayawarah secara objektif dan penuh rasa hormat, membuat keputusan seadil-adilnya, bertanggung jawab bukan hanya kepada para pengikutnya, tetapi juga yang lebih penting adalah kepada Allah SWT (Ferryanto, Zaki: 2015). Kepemimpinan dalam kondisi apapun sangat 
diperlukan, baik baik bagi diri sendiri, lingkungan keluarga, masyarakat, dan lainnya.

Karakteristik utama pemimpin menurut perspektif Islam adalah semua wirausaha muslim harus memiliki hubungan yang dekat dengan bawahan mereka. Ini sangat penting untuk membangun kepercayaan diri dan kepercayaan di antara para pekerja. Seorang wirausaha muslim harus seseorang memiliki martabat, harga diri, dan nilai moral. Namun, mereka juga harus sangat ketat dalam melakukan pekerjaan dan tanggung jawabnya, selalu berkomunikasi, memberikan pidato, saran, dan perintah. Selain itu, mereka juga harus menyediakan beberapa ide bagus, pengetahuan dan keterampilan untuk staf mereka (Yacoob, Ghani: 2012).

Selain itu, menurut Abdul Aziz Yusof (2010), seorang pemimpin dalam konteks kewirausahaan harus memiliki pengetahuan dan keterampilan. Ini karena banyak perubahan telah terjadi di banyak bidang baru-baru ini, maka pengusaha perlu berbagi pengetahuan dan keterampilan mereka kepada orang lain. Selain itu, para pemimpin juga harus dapat melakukan beberapa pemikiran cepat dalam membuat keputusan terutama mengenai masalah yang terkait dengan Isu saat ini. Pengusaha yang menjadi pemimpin harus menunjukkan contoh yang baik untuk usaha mereka. Islam menyerukan kepada para pengusaha Muslim untuk memberikan beberapa contoh yang baik kepada karyawan mereka. Hal ini karena tanpa adanya contoh yang baik dari pemimpin mereka, maka para karyawan akan gagal. Seorang wirausahawan harus memimpin dengan kejujuran dan kepercayaan. Allah SWT telah disebutkan dalam Al Quran: "Sesungguhnya, Allah memerintahkan Anda untuk memberikan kepercayaan kepada siapa mereka sudah jatuh tempo dan ketika Anda menilai di antara orang-orang untuk menghakimi dengan adil. "(QS An-Nisa: 58). Pengusaha muslim yang sangat jujur akan sangat bertanggung jawab dan dapat dipercaya dalam semua urusan mereka karena mereka tahu Allah telah melarang para hamba-Nya untuk mengkhianati kepercayaan yang diberikan kepada mereka. Menurut 
QS. al-Anfal: 27) seorang wirausahawan muslim harus melaksanakan tanggung jawabnya sebaik mungkin sehingga ia tidak akan dianggap sebagai 'munafik' (orang munafik).

Membahas kepemimpinan, telah diakui diseluruh jagad raya bahwa kepemimpinan yang sempurna itu hanyalah ada pada diri Nabi dan Rasul, karena mereka adalah hamba pilihan Allah SWT. Maka suatu keharusan bagi kita sekarang ini untuk menjadikan pela kepemimpan nabi sebagi rujukan dan tauladan dalam kepemimpinan. Salah satu caranya dengan menghidupkan kembali nilai-nilai universal kepemimpinan para Nabi dan Rasul. Diantara nabi dan rasul yang teristimewa dihadapan Allah SWT adalah Nabi Muhammad SAW. Oleh sebab itu, adalah hal yang seharusnya baggi umat

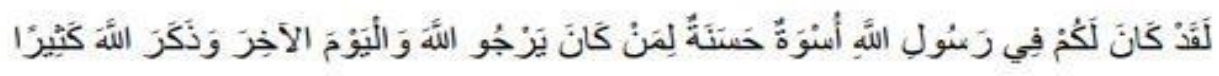

islam untuk menjadikan figur Nabi Muhammad sebagai suru tauladan rmasuk dalam hal kepemimpinan. Allah menyatakan dalam AL-Qurean dalam surah Al-Ahzab ayat 21 sebagai berikut:

Artinya: Sesungguhnya telah ada pada diri Rasulullah itu suri tauladan yang baik bagimu (yaitu) bagi orang-orang yang mengharap rahmat Allah dan (kedatangan) hari kiamat, dan ia yang banyak menyebut nama Allah.(Al-Ahzab.21).

Berdasarkan ayat tersebut jelas bagi kita bahwa Nabi Muhammad SAW adalah hamba yang diutus dan dipilih Allah SWT untuk menjadi model atau tauladan bagi semua aspek kehidupan umat sesudahnya. Termasuk salah satunya dalam hal kepemimpinan. Sesuai dengan sifat yang wajib dimiliki Nabi, ada empat model kepemimpinan yang melekat pada diri Nabi, yaitu

a. Shiddiq secara etimologi berarti benar, jujur, apa adanya, dan tidak pernah menyembunyikan sesuatu.

b. Amanah secara etimologi berarti orang yang dapat dipercaya, Nabi Muhammad sejatinya adalah orang yang dapat dipercaya untuk mengemban suatu yangdiamanahkan.

c. Tabligh menurut bahasa adalah menyampaikan, atau mengutarakan kepada orang lain. 
d. Fathanah berarti cerdas, pandai, pintar dan masih banyak lagi arti yang semisal.

Keempat model kepemimpinan Rasulullah yang dikemukakan diatas, yakni Shiddiq, amanah, tabligh, fathanah, adalah sebuah sifat dan karakter yang terbaik untuk dijadikan tauladan dalam mengembangkan potensi kepemimpinan individu maupun kelompok. Nilai-nilai yang terkandung dalam keempat sifat tersebut memiliki kekuatan yang luar biasa. Keempat sifat tersebut adalah satu kesatuan yang sinergis dan saling melengkapi. Variabel dari sifat-sifat tersebut sudah teruji kesuksesannya sebagaimana suksesnya para Nabi dan Rasul Allah. Karakter kepemimpinan yang ada pada Nabi dan Rasul sudah terbukti keberhasilannya. Tugas kita sekarang adalah hanya tinggal mengembangkan karakter kepemimpinan tersebut agar lebih adaftif dengan perkembangan zaman dan waktu.

Wajib bagi seorang pengusaha muslim untuk memerintahkan apa yang benar dan melarang apa adanya salah di antara pekerjanya, pelanggan, dan masyarakat secara keseluruhan. Sesuai dengan Allah dalam Al Qur'an: "Kamu adalah bangsa terbaik yang dihasilkan (sebagai contoh) bagi umat manusia. Anda memerintahkan apa yang benar dan melarang apa yang salah dan percaya kepada Allah. "(QS. al-Imran: 110). Dari beberapa jurnal yang telah memaparkan penjelasan mengenai pemimpin Islam dalam melakukan bisnis, bahwa pemimpin yang menjalankan sebuah wirausaha adalah seorang muslim dan memiliki beberapa karakteristik yang harus dimiliki dalam pemimpin bisnis Islam. Untuk pemimpin islam kedepannya dalam hal bisnis harus sesuai dengan prinsip-prinsip kepemimpinan bisnis Islam yaitu: 1) Memiliki martabat dan nilai moral; 2) Memiliki pengetahuan dan keterampilan; dan 3) Melakukan pemikiran cepat dalam pengambilan keputusan.

Seorang pemimpin yang beriman, akan selalu taat dan takut kepada Allah. Ia akan menjalankan pelintah-Nya dan berusaha untuk menjauhi laranganNya, khususnya dalam berbisnis. Agar bisnisnya selalu mendapat keridhaan dari Allah, maka seorang pemimpin bisnis harus mengetahui aturan dan rambu-rambu dalam berbisnis yang telah digariskan oleh Allah. 1a harus 
mengetahui ketetapan syariat Islam dalam berbisnis. Tidak boleh melanggarnya dalam keadaan apapun juga. Ia harus mendahulukan keselamatan agamanya daripada kepentingan bisnis semata. Jika ia menghadapi dua pilihan, maka ia harus memilih yang akan mendapat keridhoan Allah. Misalnya, seorang pengusaha menghadapi pilihan mendapat keuntungan besar, sementara keuntungan tersebut didapat dari hal yang syubhat atau bahkan lebih dekat kepada haram. Maka seorang pengusaha muslim, akan memilih kepentingan agamanya dan membuang keuntungan besar yang akan didapatnya itu. Jika seorang pernimpin mempunyai ketaatan dan ketakutan kepada Allah, maka keberkahan akan datang kepadanya dan kepada apa yang dipimpinnya. Sedangkan, jika kondisi usaha tersebut buruk, maka pemimpin sebaiknya melakukan pemikiran cepat dalam pengambilan keputusan yang terkait dengan masalah yang dihadapi, kemudian menyiapkan beberapa ide yang baru, pengetahuan, dan keterampilan untuk staf mereka dan jangan lupa untuk selalu mengingat Allah, bahwa keberkahan hanya datang dariNya. Sebagai pemimpin yang mempunyai pegangan Islam yang kuat, maka anda harus mampu memberikan warna kepada lingkungan bisnis anda. Kepemimpinan yang anda pegang akan mempermudah dalam memberikan warna Islam kepada bisnis. Contoh yang paling mudah dalam mewarnai lingkungan bisnis anda dengan corak Islam seperti: 1) Membuka rapat kerja bersama bawahan anda dengan membaca bismillah; 2) Jika memungkinkan tidak hanya membaca bismillah, tetapi juga membaca ayatayat Al-Qur`an.

Membiasakan karyawan dengan pola hidup Islam seperti memberi salam, dan lain sebagainya. Lingkungan kerja yang baik akan membawa dampak yang baik pula terhadap kinerja bisnis. Lingkungan bisnis adalah lingkungan yang paling rawan yang dapat menyebabkan penurunan iman seseorang.

Sebagaimana yang pernah dijelaskan oleh Rasulullah SAW bahwa pasar merupakan lingkungan yang paling buruk. Karena itu seorang pemimpin harus memperbanyak program peningkatan iman untuk dirinya dan juga terhadap bawahannya. Sehingga kesucian agama tetap terjaga, dan keberkahan tidak akan lepas daripadanya. Program - program peningkatan 
dapat seperti: 1) Mengadakan. pengajian rutin di lingkungan kerja; 2) Penggalakan program tausiyah (nasehat) setiap hari setiap memulai kerja.

Kepemimpinan bisnis Islam yang dibutuhkan adalah nilai-nilai Islam yang ada pada diri pemimpin itu sendiri untuk mnejalankan sebuah usaha yang dimilikinya. Nilai Islam disini sangat penting dan berpengaruh terhadap bisnisnya dan juga kinerja karyawan. Sesekali usaha tersebut bisa saja mengalami kerugian, karena usaha tidak selalu mendapat keuntungan. Peran pemimpin Islam dalam menangani masalah tersebut adalah tetap percaya kepada Allah bahwa semua aktivitas bisnis yang dilakukan sesuai dengan ketentuanNya, maka keberkahan akan datang pula. Setelah itu, pemimpin melakukan pengambilan keputusan secara cepat dan melakukan musyawarah kepada karyawannya untuk melakukan inovasi terbaru dalam menangani masalah yang ada. Pemimpin Islam memiliki karakter untuk bertanggung jawab atas usahanya tersebut. Oleh karena itu, jika ada masalah terhadap perusahaannya, maka pemimpin harus ikut andil dalam masalah tersebut dan tidak melimpahkan seutuhnya kepada karyawannya. Dengan demikian, bisnis dalam Islam memposisikan pengertian bisnis yang pada hakikatnya merupakan usaha manusia untuk mencari keridhaan Allah SWT. Bisnis tidak bertujuan jangka pendek, individual dan semata-mata keuntungan yang berdasarkan kalkulasi matematika, tetapi bertujuan jangka pendek sekaligus jangka panjang, yaitu tanggung jawab pribadi dan sosial dihadap masyarakat, negara dan Allah SWT. Secara umum, dapat disimpulkan bahwa kepribadian wirausaha adalah landasan dinamis untuk hubungan individu antara pengusaha dengan Allah, serta dengan orang-orang seperti karyawan, pelanggan, pemasok, pengecer, dan pedagang besar. Karena pemimpin yang baik adalah pemimpin yang memiliki hubungan yang baik dengan bawahannya.

\section{KESIMPULAN}

Pemimpin yang berhasil hendaknya memiliki beberapa kriteria yang tergantung pada sudut pandang atau pendekatan yang digunakan, apakah itu kepribadiannya, keterampilan, bakat, sifat-sifatnya, atau kewenangannya yang 
dimiliki yang mana nantinya sangat berpengaruh terhadap teori maupun gaya kepemimpinan yang akan diterapkan. Ketrampilan yang harus dimiliki pemimpin yaitu : a) Ketrampilan presentasi; b) Ketrampilan membangun tim yang kuat; c) Ketrampilan negosiasi; d) Ketrampilan bersikap baik; e) Ketrampilan memotivasi; dan f) Ketrampilan mengorganisasi.

Kepemimpinan bisnis Islam harus tetap menerapkan prinsip-prinsip Islam, baik dalam hal moral, etika, tanggung jawab dan lainnya. Keempat model kepemimpinan Rasulullah yakni Shiddiq, amanah, tabligh, fathanah, adalah sebuah sifat dan karakter yang terbaik untuk dijadikan tauladan dalam mengembangkan potensi kepemimpinan individu maupun kelompok. Keempat sifat tersebut adalah satu kesatuan yang sinergis dan saling melengkapi. Variabel dari sifat-sifat tersebut sudah teruji kesuksesannya sebagaimana suksesnya para Nabi dan Rasul Allah. Bisnis dilakukan untuk terus melakukan inovasi yang baru, sehingga ketika usaha tersebut mengalami kerugian, pemimpin serta karyawan melakukan musyawarah untuk mendapatkan inovasi-inovasi terbaru untuk mengatasi masalah tersebut.

\section{DAFTAR PUSTAKA}

Amirin, Tatang. (1984). Pokok-Pokok Teori Sistem. Jakarta: Rajawali Choliq, Abdul. (2013). Leadership. Semarang: Rafi Sarana Perkasa.

Chairunnisa, Connie. (2016). Manajemen Pendidikan dalam Multi Perspektif.

Depok: PT. Rajagrafindo Persada

Fleishman, Edwin. A. (1973). "Twenty Years of consideration and Scructure", in Current Devwloments in the Study of Leadership, ed Edwin A. Flesiman dan James G. Hunt", Carbondale: Southern 1llinois University Press.

French \& Raven. (1959). The Bases for Social Power. Zandler (eds) Group dinamics Hersey, Paul dan Kenne.

Hersey, Paul dan Kenneth H. Blanchard. (1982). Management of Organizational Behavior: Utilizing Human Resources. America: Prentice-Hall, Inc.

Machali, Imam., dan Didin Kurniawan. (2016). Menajemen Pendidikan, Konsep dan Prinsip mengelola pendidikan. Jogjakarta : ArRuzz Media.

Pfeffer, Jeffrey. (1981). Power in Organizations. Ballinger Pub Co.

Robert, B., and John F. (1960). Public Management. New York : Ronald Press. Syahril, Sulthon. (2019). Teori-teori Kepemimpinan. Jurnal Ri'ayah, Vol. 04, 
No.02, Juli-Desember.

Siagan, P. Sondang. (1983). Filsafat Administrasi. Jakarta : Gunung Agung.

Siagian, P. Sondang. (2003). Teori dan Praktek Kepemimpinan. Jakarta: Rineka Cipta.

Solihin, Ismail. (2009). Pengantar Manajemen. Jakarta: Erlangga.

Sidiq, Umar. (2014). Kepemimpinan Dalam Islam: Kajian Tematik Dalam Al-Qur'an dan Hadits. Jurnal Dialogia, Vol. 12 No. 1 Juni

Syafaruddin., dan Asrul. (2015). Kepemimpinan Pendidikan Kontemporer. Bandung :Cita Pustaka Media.

Rohmah, Noer., dan Zaenal Fanani. (2017). Pengantar Manajemen Pendidikan. Malang: Madani.

Rahmasari, Oliv Amalia. (2019). Sifat Kepemimpinan Dalam Bisnis Islam. Jurnal Manajemen Dan Bisnis Indonesia Vol. 5 No.1 Juni Hal. 32 - 42. 